\title{
Contributors to Volume 1, Fall 2013
}

\section{Volume 1, Fall 2013}

DOI: http://dx.doi.org/10.3998/mjs.12333712.0001.014

Maria Arquero de Alarcón is an Assistant Professor in Architecture and Urban Planning and Design in Taubman College at the University of Michigan. Her research, teaching and practice, as a founding partner of MAde-studio, focus on the design, representation and use of public space both as environmental infrastructure and as a field of experimentation to devise new forms of civic engagement. MAde has been recognized with an Association of Collegiate Schools of Architecture (ACSA) Faculty Design Award and two American Institute of Architects (AIA) Michigan Design Awards for their speculative work contributing to debates of green infrastructure in Detroit, and re-centering the elementary public schools as neighborhoods' cores in the city stabilization efforts. Arquero de Alarcón holds a Master of Landscape Architecture in Urban Design from the Graduate School of Design, Harvard University, a Master of Advanced Studies in Landscape Architecture from the Eidgenössische Technische Hochschule Zürich and a professional degree in Architecture, from the Escuela Técnica Superior de Arquitectura de Madrid, Polytechnic University.

Krista Badiane is an Assistant Professor at Aquinas College in Grand Rapids, Michigan and a PhD Candidate at the University of Michigan. Her current research focuses on climate change as a social change process within corporations over time. She recently published "Hybrid Organizations as Agents of Positive Social Change: Bridging the For-Profit \& Non-Profit Divide" with Andrew Hoffman and Nardia Haigh. She was also a commentator in the Journal of Current Anthropology special edition on new conceptual and methodological understandings of the corporate form. She received a Masters in Environmental Management from Duke University and a Bachelor of Arts and Science from the University of Michigan.

Rosina Bierbaum is a Professor of Natural Resources and Environmental Policy with appointments in both the School of Natural Resources \& Environment and the School of Public Health at the University of Michigan. She served as Dean of the School of Natural Resources \& Environment from October 2001 to October 2011. Currently, she serves as one of President Obama’s advisors on the President's 
Council of Advisors on Science and Technology (PCAST), a group of experts tasked with advising the President directly to help the administration formulate policy in areas where understanding of science, technology, and innovation are key to forming responsible and effective policy. Dr. Bierbaum is a board member for the Wildlife Conservation Society, the Federation of American Scientists, The Energy Foundation, Environmental and Energy Study Institute, and the Gordon E. and Betty I. Moore Foundation. Prior to coming to the University of Michigan, Dr. Bierbaum was the Acting Director of the White House Office of Science and Technology Policy (OSTP). She also directed the first Environment Division at OSTP from 1995-2001. She received her PhD from the State University of New York and her Bachelors in Biology and English from Boston College.

David Bieri is an Assistant Professor of Urban and Regional Planning at the University of Michigan, Ann Arbor and previously held various positions at the Bank for International Settlements in Switzerland, most recently as the Adviser to the CEO. His main research and teaching interests are at the intersection of urban planning and real estate economics, public finance and economic geography, including spatial features of real estate credit flows and local economic development within the broader context of financialization. Bieri's work has been published in the Cambridge Journal of Regions, Society and Economy, in Industry and Innovation, and in the Journal of Fixed Income. Bieri received his PhD from the School of Public and International Affairs at Virginia Tech. He holds a M.Sc. in corporate and international finance from the Durham University (UK) and a B.Sc.(hons) in economics from the London School of Economics.

Alex Bryan is a PhD candidate in the Department of Atmospheric, Oceanic, and Space Sciences at the University of Michigan. He studies the interactions between the land and atmosphere that influence air quality and climate. He received the $\mathrm{Na}$ tional Center For Atmospheric Research (NCAR) Graduate Student Visitor Award in 2010, allowing him to study amongst prominent research scientists in his field for three months. He received a Bachelor of Science in meteorology from Valparaiso University.

Rachel Cable is currently a research assistant in the Department of Ecology and Evolutionary Biology at the University of Michigan. Her current projects include the completion and publication of her research on human-gelada interactions mentioned in the article in this issue and an analysis of mammalian biodiversity across 
areas of complex topography. She earned her Master of Science degree in Ecology and Evolutionary Biology from the University of Michigan and her Bachelor of Science degree in Biology from the University of Texas at Austin.

Scott D. Campbell is an Associate Professor of Urban and Regional Planning in the Taubman College of Architecture and Urban Planning at the University of Michigan. His research and teaching are in the areas of planning theory and history, regional economic development, sustainable development, regional planning, and research methods. His writing on sustainable development won a National Planning Award from the American Planning Association. He received a PhD and Master of City Planning from the University of California, Berkeley, and a Bachelor of Arts from Stanford University.

Susan Cheng is a PhD candidate in Ecology and Evolutionary Biology at the University of Michigan. Her current research investigates how cloud conditions impact climate by interacting with changing forest canopy structure to control rates of photosynthesis and forest carbon dioxide uptake. She has recently earned a two-year fellowship from the University of Michigan Graham Environmental Sustainability Institute and a research award from the Michigan Space Grant Consortium. She received a MS in ecology and evolutionary biology from the University of Michigan and a BA in environmental science from Columbia University.

Tara Clancy is a PhD candidate in the Civil \& Environmental Engineering Department at the University of Michigan. Her research focuses on the microbial ecology of drinking water, arsenic removal technologies, and disposal of arsenic-bearing waste. She has been awarded the NSF Graduate Research Fellowship and is a Graham Environmental Sustainability Institute Doctoral Fellow. She received a Master of Science in Engineering in Environmental Engineering from the University of Michigan and a Bachelor of Science in Environmental Engineering from Rensselaer Polytechnic Institute.

Laura Cole is an Assistant Professor of Interior Architecture at the University of North Carolina at Greensboro. Her work focuses on the social dimensions of green buildings, with a particular focus on the experiences of youth in green school buildings. Laura is an emerging scholar in the area of "Teaching Green Buildings," with a forthcoming publication in Environmental Education Research. She received her $\mathrm{PhD}$ in Architecture and Natural Resources from the University of Michigan. 
Paul J. Coseo is an Adjunct Lecturer in the Urban and Regional Planning Program at the University of Michigan. He examines how urban physical characteristics contribute to urban heat islands and residents' heat vulnerability. He received his $\mathrm{PhD}$ in Urban and Regional Planning from the University of Michigan, a Master of Landscape Architecture from the University of Michigan, and a Bachelor of Science in Meteorology from Central Michigan University.

Irem Daloglu is a graduate of the $\mathrm{PhD}$ program in the School of Natural Resources and Environment at University of Michigan, where she was a Graham Doctoral Fellow. Her current research involves modeling coupled human and natural systems with a special focus on understanding impacts of farmer adoption of conservation practices on downstream water quality. In 2012, her work on Lake Erie eutrophication was published in Environmental Science and Technology. Before joining School of Natural Resources at University of Michigan, she completed her Master of Science in Engineering Management from Northeastern University in Boston, MA.

Brian Ellis is an Assistant Professor and Michigan Society Fellow at the University of Michigan in the department of Civil and Environmental Engineering. His research interests cover topics related to the sustainable and safe development of emerging energy technologies, including studying the environmental impacts of hydraulic fracturing. Dr. Ellis received his $\mathrm{PhD}$ and Master's degrees in Civil and Environmental Engineering from Princeton University and holds Bachelor's degrees in Environmental Geosciences and Economics from the University of Michigan.

Alexi Ernstoff is a researcher in the Impact and Risk Modeling (iMOD) laboratory in Environmental Health Sciences in the School of Public Health. Her current research investigates chemical exposures due to consumer products, such as cosmetics and food products. Her passion is raising public awareness about sustainable food systems and has received several awards due to her community work with local organizations and businesses, such as South Eastern Michigan Stewardship Coalition and Rap for Food. She received a Master of Engineering in Environmental Engineering from the University of Michigan and a Bachelor of Arts with honors in Geology from Bryn Mawr College.

Andrew (Andy) Hoffman is the Holcim (US) Professor of Sustainable Enterprise at the University of Michigan, a position that holds joint appointments at the Stephen 
M. Ross School of Business and the School of Natural Resources \& Environment. Within this role, Andy also serves as Director of the Frederick A. and Barbara M. Erb Institute for Global Sustainable Enterprise. In his research, Andy uses organizational, network and strategic analyses to assess the implications of environmental issues for business. He recently served as Chair of the Organizations \& the Natural Environment Division of the Academy of Management and was recently awarded the Maggie Prize, JMI Breaking the Frame Award, Connecticut Book Award, and the Aldo Leopold Leadership Fellowship. He holds a joint PhD in Management and Civil \& Environmental Engineering from MIT.

Darshan Karwat is a postdoctoral fellow in the Department of Mechanical Engineering at the University of Michigan. He completed his PhD in Aerospace Engineering and Sustainability Ethics in August 2012 at the University of Michigan. His current research explores the combustion chemistry of alternative fuels when blended with traditional fossil fuels, as well as the development of a framework of activist engineering that incorporates social and ecological justice concerns into engineering work. He co-founded the Student Sustainability Initiative at the University of Michigan in 2008 and will be joining the Innovation Team at the U.S. Environmental Protection Agency as a AAAS Fellow in September.

Dana Kornberg is a $\mathrm{PhD}$ candidate in the combined program of Sociology and Urban and Regional Planning at the University of Michigan. Her research investigates the politics of urban change, particularly those related to informality and environmentalism. She is currently collecting evidence for an ethnographic dissertation on state planning practices and the informal recycling sector in Delhi, India. She received a Master of Arts degree from the University of Texas at Austin in South Asian Studies and a Bachelor of Arts from Florida State University.

Larissa Larsen is an Associate Professor of Urban and Regional Planning at the University of Michigan. Her current research focuses on identifying environmental inequities in the built environment and advancing issues of urban sustainability and social justice. Some of her past research has examined urban heat islands, water consumption, and neighborhood mobilization against environmental problems. Most of her current work involves climate adaptation planning and urban heat island studies. She received her PhD in Urban Planning from the University of Illinois at Urbana-Champaign. 
Jen Maigret is an Assistant Professor of Architecture at Taubman College at the University of Michigan. Her design research and practice, as a founding partner of MAde-studio, engages the generative potential of complex, environmental systems related to the material, cultural and formal expression of architecture. MAde-studio has most recently garnered recognition with an ACSA Faculty Design Award and two AIA Michigan Design Awards. Maigret holds a Master of Architecture from the University of Michigan, a Master of Science in Ecology, Evolutionary and Organismal Biology from the University of Michigan and a Bachelor of Arts in Biology from Hartwick College.

Erica Morrell is a PhD candidate in public policy and sociology at the University of Michigan. Her current research examines the comparative politics of local food policy domains in Detroit and Cleveland. Erica is an editor of the Michigan Journal of Sustainability, a co-editor of this volume, and the author of one article in this volume that draws off findings from a prior research project. She received a Bachelor of Arts from Boston University in 2007.

Nicholas B. Rajkovich is a PhD candidate in the Urban and Regional Planning Program at the University of Michigan. His current research evaluates the effectiveness of weatherization programs to help communities adapt to climate change. In 2011, he was awarded a Graduate Research Fellowship from the National Science Foundation and a Doctoral Fellowship from the Graham Environmental Sustainability Institute at the University of Michigan. He received a Master of Architecture from the University of Oregon and a Bachelor of Architecture from Cornell University.

Don Scavia is the Graham Family Professor of Sustainability and Director of the Graham Sustainability Institute. He is also Professor of Natural Resources, Professor of Environmental Engineering, and Special Counsel to the University of Michigan President for Sustainability. His research interests include the effects of natural and anthropogenic stresses on Great Lakes and marine ecosystems, with a focus on the use of models and integrated assessments in transferring knowledge to decision makers. He holds a $\mathrm{PhD}$ in Environmental Engineering from University of Michigan and a MS and BS in Environmental Engineering from Rensselaer Polytechnic Institute. 
Laura S. Sherman is a postdoctoral research scientist in the Department of Earth and Environmental Sciences at the University of Michigan. Her current research focuses on the emission, transport, and deposition of toxic air pollutants and their impacts on human populations. She recently received the ProQuest Distinguished Dissertation Award and John Dorr Graduate Academic Achievement Award for her accomplishments at University of Michigan. She earned a PhD in Earth and Environmental Sciences from the University of Michigan and a Bachelor of Sciences with Honors and Distinction from Stanford University.

Allison Steiner is an associate professor of atmospheric sciences in the Department of Atmospheric Oceanic and Space Sciences and the Department of Earth and Environmental Sciences at the University of Michigan. Her research uses state-of-theart models to explore the complex interactions of the biosphere and atmosphere with the goal of understanding the natural versus human influence on climate and atmospheric chemistry. She received a B.S. degree in chemical engineering from Johns Hopkins University and $\mathrm{PhD}$ in atmospheric science from Georgia Institute of Technology.

Missy Stults is a Science Research Fellow and a doctoral student at the University of Michigan. She is currently working on issues related to urban resilience to climate change. As part of her work, Missy is co-developing the Adaptation Chapter for the U.S. National Climate Assessment, working on a typology of adaptation actions being implemented in developing countries, and helping enhance municipal preparedness to climate change in the Great Lakes region. Before joining the University of Michigan, Missy was the national Climate Director for ICLEI-Local Governments for Sustainability where she worked with over 600 local governments to advance their climate mitigation, climate adaptation, and sustainability efforts. Missy received a Masters in Climate and Society from Columbia University and a Bachelors of Science from the University of New England in Marine Biology and Environmental Science.

Brian D. Vickers is a PhD candidate in the Cognition in Cognitive Neuroscience program at the University of Michigan. His current research assesses how individuals make decisions to consume as well as decisions to help others and the environment using multiple methodologies (e.g., behavioral testing, physiology, fMRI). $\mathrm{He}$ received a Bachelor of Arts from the University of California, Santa Cruz. 